\title{
2010s-26
}

\section{Economic Restructuring and Total Factor Productivity Growth: Tunisia Over the Period 1983-2001}

\author{
Sofiane Ghali, Pierre Mohnen
}

\begin{tabular}{c}
\hline Série Scientifique \\
Scientific Series
\end{tabular}

\author{
Montréal \\ Juin 2010
}

(C) 2010 Sofiane Ghali, Pierre Mohnen. Tous droits réservés. All rights reserved. Reproduction partielle permise avec citation du document source, incluant la notice (C).

Short sections may be quoted without explicit permission, if full credit, including (C) notice, is given to the source.
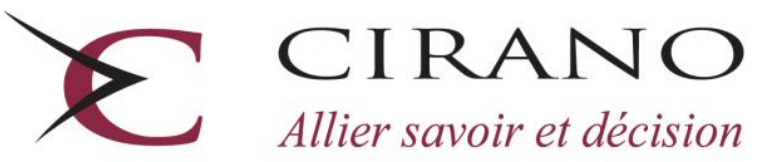

Allier savoir et décision

Centre interuniversitaire de recherche en analyse des organisations 


\section{CIRANO}

Le CIRANO est un organisme sans but lucratif constitué en vertu de la Loi des compagnies du Québec. Le financement de son infrastructure et de ses activités de recherche provient des cotisations de ses organisations-membres, d'une subvention d'infrastructure du Ministère du Développement économique et régional et de la Recherche, de même que des subventions et mandats obtenus par ses équipes de recherche.

CIRANO is a private non-profit organization incorporated under the Québec Companies Act. Its infrastructure and research activities are funded through fees paid by member organizations, an infrastructure grant from the Ministère du Développement économique et régional et de la Recherche, and grants and research mandates obtained by its research teams.

\section{Les partenaires du CIRANO}

Partenaire majeur

Ministère du Développement économique, de l'Innovation et de l'Exportation

\section{Partenaires corporatifs}

Banque de développement du Canada

Banque du Canada

Banque Laurentienne du Canada

Banque Nationale du Canada

Banque Royale du Canada

Banque Scotia

Bell Canada

BMO Groupe financier

Caisse de dépôt et placement du Québec

Fédération des caisses Desjardins du Québec

Gaz Métro

Hydro-Québec

Industrie Canada

Investissements PSP

Ministère des Finances du Québec

Power Corporation du Canada

Raymond Chabot Grant Thornton

Rio Tinto

State Street Global Advisors

Transat A.T.

Ville de Montréal

\section{Partenaires universitaires}

École Polytechnique de Montréal

HEC Montréal

McGill University

Université Concordia

Université de Montréal

Université de Sherbrooke

Université du Québec

Université du Québec à Montréal

Université Laval

Le CIRANO collabore avec de nombreux centres et chaires de recherche universitaires dont on peut consulter la liste sur son site web.

Les cahiers de la série scientifique (CS) visent à rendre accessibles des résultats de recherche effectuée au CIRANO afin de susciter échanges et commentaires. Ces cahiers sont écrits dans le style des publications scientifiques. Les idées et les opinions émises sont sous l'unique responsabilité des auteurs et ne représentent pas nécessairement les positions du CIRANO ou de ses partenaires.

This paper presents research carried out at CIRANO and aims at encouraging discussion and comment. The observations and viewpoints expressed are the sole responsibility of the authors. They do not necessarily represent positions of CIRANO or its partners. 


\title{
Economic Restructuring and Total Factor Productivity Growth: Tunisia Over the Period 1983-2001*
}

\author{
Sofiane Ghali ${ }^{\dagger}$ Pierre Mohnen
}

\begin{abstract}
Résumé
Cet article mesure et décompose la croissance de la productivité totale des facteurs (PTF) potentielle en Tunisie sur la période 1983 à 2001. La croissance de la PTF potentielle est définie comme le déplacement de la frontière d'efficience de l'économie, qui est déterminée chaque année à partir d'un programme de programmation linéaire, un genre d'analyse DEA macroéconomique. Cette croissance de la PFT potentielle est décomposée de deux façons : une fois en termes de sources de la croissance, à savoir le changement technologique, les variations de taux de change, les changements d'efficience et utilisation des ressources ; et une fois en termes de bénéficiaires de cette croissance, à savoir le travail, décomposé en cinq types, le capital, décomposé en deux types, et le déficit permis de la balance commerciale.

Nous trouvons que la PTF potentielle a cru de $1 \%$ par an après l'introduction du programme d'ajustement structurel de 1987. La croissance de la PTF potentielle est surtout due au résidu de Solow, qui capte le progrès technologique, et a surtout bénéficié au travail non-qualifié. Les termes de l'échange ne furent pas favorables à la Tunisie. Après 1992, la frontière d'efficience s'est déplacée vers l'extérieur, mais la Tunisie s'est distancée de sa frontière d'efficience.
\end{abstract}

Mots clés : croissance de la productivité totale des facteurs, tableaux entrée-sortie, frontière d'efficience, Tunisie.

In this paper we aim to measure and decompose the growth of frontier total factor productivity (TFP) in Tunisia over the period 1983-2001. We define frontier TFP growth as the shift of the economy's production frontier, which we obtain by solving for each year a linear program, a sort of aggregate DEA analysis. We then decompose this aggregate frontier TFP growth into changes in technology, terms of trade, efficiency and resource utilization. We can also attribute frontier TFP growth to its main beneficiaries: labor, decomposed into five types, capital, decomposed into two types, and the allowable trade deficit.

We find that frontier TFP grew by about $1 \%$ a year after the introduction of the structural adjustment program of 1987. Labor, in particular unskilled labor, was the main beneficiary of frontier TFP growth. The Solow residual reflecting technological change was the main driver of frontier TFP growth. The terms of trade were not favorable to Tunisia. After 1992, while the Tunisian efficiency frontier moved outwards, the country moved away from its efficiency frontier.

Keywords: total factor productivity growth, input-output, frontier analysis, Tunisia.

Codes JEL : O47, O55

\footnotetext{
* The authors wish to thank H. Fehri, M. Goaied, F. Kriaa, M. Lahouel, F. Lakhoua, J. Nugent, A. Szirmai, T. ten Raa and an anonymous referee from the Economic Research Forum for their critical comments on earlier versions of this paper.

${ }^{\dagger}$ F.S.E.G.N, University of 7 November at Carthage, ERF, UAQUAP.

tUNU-MERIT, University of Maastricht, CIRANO, and Sanjaya Lall Programme at Oxford University. UNUMERIT, Maastricht University, P.O. Box 616, 6200 MD Maastricht, The Netherlands, E-mail:

Mohnen@merit.unu.edu.
} 


\section{Introduction.}

With the structural adjustment program introduced in 1986 and supported by the International Monetary Fund and the World Bank a policy of gradual trade liberalization was pursued, first by implementing the current account convertibility, followed by the accession to the GATT accords and by a free trade association with the European Union in 1995. The price regulation based on a cost plus system encouraging excessive capitalization was replaced by a price liberalization policy. Starting in 1996, various micro structural adjustment programs were initiated with the support of the European Union to help the small Tunisian enterprises to acquire the necessary capabilities to face competition with the EU.

It is interesting to revisit the various drivers of productivity growth in a unified framework and to examine whether the structural reforms improved Tunisia's growth potential. Building on ten Raa and Mohnen (2002) and Ghali and Mohnen (2003), a general equilibrium model of the Tunisian economy is used to estimate the total factor productivity (TFP) growth rate at the sector and at the aggregate level between 1983 and 2001. This TFP measure indicates the sources of strength and the bottlenecks to Tunisia's economic growth.

Conventionally, TFP is defined as the ratio of an output index to an input index (see Diewert (1992)). Its growth therefore represents the growth of output that cannot be explained by the growth in the inputs. Under certain conditions, among which constant returns to scale, optimal factor holdings and marginal cost pricing, TFP growth, as measured by the Solow residual, captures the technology shift. ${ }^{1}$ It is, however, debatable whether these restrictive conditions hold. Moreover, in an open economy it makes sense to redefine productivity as the final demand achievable with the domestic resources and the extent of the trade deficit (Diewert and Morrison (1986)). Another strand of literature turning around the Malmquist index distinguishes between movements of and towards the frontier, splitting TFP growth into changes in efficiency and changes in technology (see Caves, Christensen and Diewert (1982)).

The approach that we adopt for measuring and interpreting TFP growth is cast in a general equilibrium model of an open economy that does not rely on observed market prices to infer marginal productivities, but only on the fundamentals of the economy, i.e. technologies, preferences and endowments. To reduce the errors of measurement in total factor productivity (Jorgenson and Griliches (1967), Barro (1999)) we disaggregate the inputs by quality classes, i.e two types of capital and five types of labor.

The paper is organized as follows. In section II we briefly review the various measures and interpretations of TFP. After that, in section III, we present our model of the Tunisian economy, the calculation of the efficiency frontier and the data

\footnotetext{
${ }^{1}$ The Solow residual is defined as

$\frac{A_{t}}{A_{t}}=\frac{Q_{t}}{Q_{t}}-S_{K_{t}} \frac{K_{t}}{K_{t}}-S_{L_{t}} \frac{L_{t}}{L_{t}}$
}

where $\mathrm{K}$ and $\mathrm{L}$ represent capital, labor, $\mathrm{S}_{\mathrm{K}}$ and $\mathrm{S}_{\mathrm{L}}$ their respective output elasticities, and $\mathrm{A}_{t}$ measures the shift of the production function (here specified in terms of value added, $\mathrm{Q}$ ). 
sources. We then turn to the application of this model to the Tunisian economy. In section IV we analyze Tunisia's TFP growth first at a macro level and then at the sector level. We conclude by summarizing our main findings and suggesting further lines of research.

\section{The measurement and meaning of TFP}

TFP has been measured and interpreted in many different ways (see the surveys by Diewert (1992), Balk (1998), Grosskopf (2001)). The first choice is with respect to the number of inputs. Materials are sometimes ignored or factored out by an assumption of separability of materials and primary inputs so that output is defined as value-added. Each individual input might itself result from the aggregation of many heterogeneous parts. If the input components are given the same marginal productivities in the face of heterogeneity, we have a measurement error, similar to the one that results from unaccounted for quality changes. Our model is based on input-output tables that explicitly incorporate the intermediate inputs, it distinguishes between two types of capital and five types of labor.

Most of the time TFP is measured in closed economies, ignoring possible substitutions between domestically produced and imported inputs. In an open economy it is possible to increase output without producing more inputs, simply by increasing the amount of imported inputs. It is therefore important in open economies to adjust TFP to allow for imports, by redefining it as the growth in final domestic demand minus the growth of the primary inputs, which include the allowable trade deficit. As a result, TFP can now be affected by changes in the terms of trade. TFP accounting in open economies have been handled by Diewert and Morrison (1986) and Kohli (1991). Our model recognizes the openness of the Tunisian economy.

In the productivity literature there are two ways to measure marginal productivities and hence TFP. The first one is the index number approach where observed prices are supposed to equate marginal values. The second one is the parametric approach where marginal productivities are estimated from a production function or a dual representation of it. In the former approach TFP measurement rests on the assumption of constant returns to scale, optimal factor holdings and marginal cost pricing. The latter approach can overcome these restrictions by modeling the departures from perfect competition, although in practice it is rare to relax all three assumptions at the same time. The latter approach requires the use of specific functional forms whereas the former does not, unless it is based on index numbers that are exact for specific functional forms.

A third strand of literature, starting with Farrell (1957), distinguishes between technology shifts and changes in efficiency by using the concept of a distance function. The output distance function measures the greatest possible expansion of output for given levels of inputs, and the input distance function measures the greatest possible contraction in inputs for a given level of output. The distance function and the resulting Malmquist productivity index can again be obtained non-parametrically by using linear programming techniques, known as «Data Envelopment Analysis » (DEA) or be estimated through a stochastic frontier function with an asymmetrically distributed random error term (for a recent examples of DEA and stochastic frontier 
analysis, see Färe, Grosskopf, Norris and Zhang (1994) and Fuentes, Grifell-Tatjé and Perelman (2001) resp.).

We shall depart from all previous approaches and follow the approach proposed by ten Raa and Mohnen (2002), which combines input-output analysis and linear programming. It is a sort of macroeconomic DEA approach, defining a frontier for the entire economy given its interindustry linkages, the technologies in each sector, the final demand preferences and the endowments of primary inputs. Using this approach we can follow the evolution of efficiency in the use of primary inputs and factor allocations (the distance to the frontier) and the evolution of the production possibility frontier, in other words the potential of the Tunisian economy.

The theoretical framework naturally leads to two macroeconomic decompositions of TFP growth, one in terms of the individual contributions of the primary inputs and one in terms of drivers of TFP growth: changes in technologies (the Solow residual), the terms of trade, efficiency and resource utilization.

\section{The competitive benchmark}

We adopt the measure of frontier TFP growth defined in ten Raa and Mohnen (2002) and we apply it to the model for Tunisia used in Ghali and Mohnen (2003). The idea is to determine the frontier of the economy by factor reallocations across sectors, international specialization, and full resource utilization. For that, we define a competitive benchmark obtained by a sort of DEA analysis at the macro level. Technology, preferences and factor endowments are taken as exogenous. The aim is to determine what the economy's frontier would be in a world of perfect competition.

On the basis of the fundamentals of the economy, i.e. the technologies, the preferences, the endowments of labor and capital, and the world prices of tradable commodities (because we assume that Tunisia is a small open economy), we set up a linear programming problem, or activity analysis model, designed to maximize domestic final demand given those fundamentals. For each year we solve the linear programming problem, which determines the optimal allocation of resources among the various sectors of the economy, the optimal production pattern and the optimal trade in tradable commodities. In this general equilibrium setting shadow prices support the optimal quantities. In this way we trace the economy's frontier in terms of potential production and consumption and its evolution over time. From these optimal quantities and shadow prices we measure potential TFP growth and we decompose it in its constituent parts. Observed prices and quantities do not enter the TFP expression directly. They only serve as basic inputs into the computation of the economy's efficiency frontier. This frontier corresponds to a hypothetical competitive world where technology, preferences and endowments are exogenous. It corresponds thus to a long-term optimum. Adjustment costs from the observed to the optimal allocation of resources are not taken into account. We could conceive of a dynamic programming problem where technologies, preferences and endowments are endogenized with given initial conditions and with adjustment costs or other rigidities constraining the immediate adjustment to a long-run equilibrium. We leave these extensions for future work. 
Formally, the efficient state of the economy is obtained by solving the following linear programming problem:

$\max _{t, s, g}(D F D) t$ subject to the following constraints:

$$
\begin{aligned}
\left(V^{\prime}-U\right) s & \geq f t+J g \\
\left(L_{1}+L_{2}+L_{3}+L_{4}+L_{5}\right)^{\prime} s+\left(l_{1}+l_{2}+l_{3}+l_{4}+l_{5}\right) t & \leq N_{1}+N_{\mathbf{2}}+N_{\mathbf{3}}+N_{\mathbf{4}}+N_{\mathbf{5}} \\
\left(L_{\mathbf{2}}+L_{\mathbf{3}}+L_{\mathbf{4}}+L_{5}\right)^{\prime} s+\left(l_{\mathbf{2}}+l_{\mathbf{3}}+l_{\mathbf{4}}+l_{\mathbf{5}}\right) t & \leq N_{\mathbf{2}}+N_{\mathbf{3}}+N_{\mathbf{4}}+N_{\mathbf{5}} \\
\left(L_{\mathbf{3}}+L_{\mathbf{4}}+L_{\mathbf{5}}\right)^{\prime} s+\left(l_{\mathbf{3}}+l_{\mathbf{4}}+l_{\mathbf{5}}\right) t & \leq N_{\mathbf{3}}+N_{\mathbf{4}}+N_{\mathbf{5}} \\
\left(L_{\mathbf{4}}+L_{\mathbf{5}}\right)^{\prime} s+\left(l_{\mathbf{4}}+l_{\mathbf{5}}\right) t & \leq N_{\mathbf{4}}+N_{\mathbf{5}} \\
L_{\mathbf{5}}^{\prime} s+l_{\mathbf{5}} t & \leq N_{\mathbf{5}} \\
\hat{K_{e}} \hat{C} s & \leq K_{e} \\
\left(K_{s}^{\prime}\right) s & \leq\left(K_{s}^{\prime}\right) e \\
-\pi^{\prime} g & \leq D \\
s & \geq \mathbf{0}
\end{aligned}
$$

where

$D F D=\tilde{p}^{\prime} f+\tilde{w}^{\prime} l$

$\tilde{p}=(\mathrm{mx} 1)$ vector of observed commodity prices, where $\mathrm{m}$ is the number of commodities

$f=(\mathrm{mx} 1)$ vector of domestic final demand

$\tilde{w}=(\mathrm{vx} 1)$ vector of observed annual labor earnings per worker in the non-business sector, where $\mathrm{v}$ is the number of types of labor

$l=(\mathrm{vx} 1)$ vector of employment in the non-business sector

$t=$ (scalar) level of domestic demand

$s=(\mathrm{nx} 1)$ vector of activity levels, where $\mathrm{n}$ is the number of sectors

$g=\left(\mathrm{m}_{\mathrm{T}} \times 1\right)$ vector of net exports, where index $\mathrm{T}$ stands for tradable commodities

$V=$ make matrix (nxm), indicating how much of each commodity is produced in each sector

$U=$ use matrix (mxn), indicating how much of each commodity is used in each sector as intermediate inputs

$J=\left(\mathrm{nxm}_{\mathrm{T}}\right)$ matrix selecting tradables

$L_{i}=(\mathrm{nx} 1)$ matrix of employment by sector for labor type $\mathrm{i}$

$N_{i}=$ (scalar) labor force of labor type i

$K_{e}=(\mathrm{nx} 1)$ vector of available capital equipment

$K_{s}=(\mathrm{nx} 1)$ vector of available capital buildings

$\mathrm{C}=(\mathrm{nx} 1)$ vector of capacity utilization rates in each sector

$\pi=\left(\mathrm{m}_{\mathrm{T}} \mathrm{x} 1\right)$ vector of world prices for tradable commodities relative to a domesticfinal-demand-weighted average of world prices

$D=$ observed trade deficit $=-\pi^{\prime}\left(V^{\prime} e-U e-f\right)_{T}$

$e=$ unity vector of appropriate dimension

$\wedge=$ diagonalization operator.

The decision variables are the level of domestic final demand $(\mathrm{t})$, the sector activity levels (s) and net exports (g). They are determined so as to maximize domestic final demand subject to three sets of constraints. The first set are the commodity 
balances (1), which stipulate that net production in each sector has to be sufficient to satisfy domestic final demand and net exports. The second set, constraints (2) to (8), state that the inputs used in each sector may not exceed total disposable inputs. Equipment is taken to be sector-specific. In other words, we assume putty-clay technologies. Once installed in a sector, equipment cannot be disassembled and relocated somewhere else in the economy. In contrast, buildings are assumed to be malleable. The capital constraint is binding in a sector when it reaches full capacity utilization. For labor, we distinguish five different types, each corresponding to a certain level of qualification and expertise. Workers can always be allocated to jobs requiring lower (but not higher) qualifications, which is not unrealistic in the case of Tunisia, where due to the high unemployment rate among educated individuals between ages 25 and 29, many take jobs that underutilize their skills (World Bank, 2008)) . Part of the labor force is affected to the non-business sector, which essentially comprises services directly consumed by final demand (government services, services provided by non-profit institutions). The last constraint (9) posits that the trade deficit at optimal activity levels may not exceed the observed trade deficit. To increase their level of consumption, Tunisians can import from abroad, but only up to a certain level, which is conservatively taken to be the observed trade deficit. Without constraint (9), Tunisia could reach an infinite value for its objective function by importing without limits. The assumption of a small open economy with exogenous world prices for the tradable commodities is not unrealistic in the case of Tunisia. The observed activity levels correspond to the following values: $t=1, \mathrm{~s}=\mathrm{e}$, and $\mathrm{D}=-\pi^{\prime}\left(\mathrm{V}^{\prime} \mathrm{e}-\mathrm{Ue}-\mathrm{f}\right)_{\mathrm{T}}$. The observed state of the economy is thus our point of reference. Efficiency derives from full capacity utilization, optimal factor allocations across sectors, and international specialization.

The prices sustaining this general equilibrium resource allocation are derived from the dual program:

$$
\begin{aligned}
& \min _{p, w, r, \varepsilon} w^{\prime} N+r^{\prime} M+\varepsilon D \text { subject to the following constraints } \\
& p^{\prime}\left(V^{\prime}-U\right) \leq w^{\prime} L^{\prime}+r^{\prime} K^{\prime} \\
& p^{\prime} f+w^{\prime} l=D F D \\
& p^{\prime} J=\varepsilon \pi^{\prime} \\
& p \geq 0, w_{5} \geq w_{4} \geq w_{3} \geq w_{2} \geq w_{1} \geq 0 ; r \geq 0 ; \varepsilon \geq 0 .
\end{aligned}
$$

where $\mathrm{p}, \mathrm{w}, \mathrm{r}$ and $\varepsilon$ are respectively the shadow prices of commodities, the five types of labor, the capital stocks in equipment in each sector, the capital stock in buildings for the whole economy, and the trade deficit ${ }^{2}, L^{\prime}$ is a $(5 \mathrm{xn})$ matrix of employment by type of labor and sector, $\mathrm{N}$ is a $5 \times 1$ vector of total labor force by type of labor, $\mathrm{M}=\left[K_{e} \mid\left(K_{s}^{\prime}\right) e\right], \mathrm{K}=\left[K_{e} \hat{C} \mid K_{s}\right]$, and $\mid$ is the vertical concatenation operator. By the theorem of complementary slackness, a shadow price is positive only if the corresponding constraint in the primal is binding. The shadow prices $\mathrm{w}$ and $\mathrm{r}$ denote the marginal values of an additional unit of the respective inputs. If at a certain level of qualification the labor constraint is tight, it earns a markup over the level of

\footnotetext{
${ }^{2}$ Notice that the shadow price of the highest qualified labor type is the sum of the shadow prices of constraints (2) to (6).
} 
qualification just below. A sector with less than full capacity utilization earns a zero rate of return on a marginal capital investment, for the very simple reason that it in no excess demand, as unused capital is still available. The shadow price $\varepsilon$ of the trade balance indicates the marginal value in terms of attainable domestic final demand of an additional allowed dinar of trade deficit. The inequalities (10) indicates that at the optimal solution of the linear program the prices of active sectors equal average cost, and hence that the optimal solution can be interpreted as a competitive equilibrium. By the complementary slackness conditions, it can also be said that a sector is active only if it makes no loss. Condition (11) is a normalization condition akin to the choice of a numeraire. At this point it should be noted that the observed prices $\tilde{p}$ and $\tilde{w}$ in no way affect the optimal activity levels, they affect the shadow prices only through the normalization rule (11), i.e. shadow prices are such that on average they reproduce the existing prices ${ }^{3}$. By equality (12) domestic prices for tradable commodities may differ from world prices only by a certain constant $\varepsilon$, which can be interpreted as the exchange rate compatible with the purchasing power parity. All quantities are expressed in base-year prices, except labor, which is denoted in man-years. The observed prices $\tilde{p}$ and $\tilde{w}$ are normalized by their base-year values $(\tilde{p}=1$ in 1990 , $\tilde{w}=$ observed vector of wages in 1990). Hence, all shadow prices are expressed in base year prices.

The basic data that we use are the input-output tables of Tunisia for the period 1983-2001. Labor is disaggregated into five levels of qualification: manual workers and trainees, machine operators, foremen, technicians, and engineers and administrators. Data on employment and earnings in the business and the nonbusiness sectors are taken from employment and population surveys conducted by INS (Institut National de la Statistique). The number of unemployed workers in category $i(i=1, \ldots, 5)$ is computed from the proportions of unemployed workers in the qualified and low-qualified groups and the proportion of workers that the five categories represent in the two groups. Capital is disaggregated into buildings and equipment. The estimates of capital stocks are taken from the national income accounts of INS. Unfortunately no data are available at the manufacturing sector level for the ICT and non ICT capital goods to measure the contribution of ICT capital to productivity growth and to estimate the complementarity between ICT use and skilled workers. Only economy-wide data on ICT are available in Tunisia. Capacity utilization rates are borrowed from a study performed by the «Institut d'Economie Quantitative» (1996). For more details on the data sources and constructions the reader is referred to Ghali and Mohnen (2003). For the industry definitions, see appendix I.

In our model labor is mobile across sectors and gets assigned first to the sector with the greatest value added until this sector reaches its full capacity, then to the next sector with the greatest value added until that one reaches its full capacity and so on. The wage rate for a certain type of labor is thus determined by its marginal productivity in the last sector that is activated. The marginal social values of workers of different qualifications are reflected in their shadow wages (table 1). In 1983, the availability of one more worker in the economy could have increased its well-being by 246 dinars per year (in 1990 prices). The fact that high qualified workers did not

\footnotetext{
${ }^{3}$ It could be argued, though, that observed technologies and preferences are the result of actual prices, which may not be competitive.
} 
potentially earn more than low-qualified workers is equivalent to saying that there was no justification for the observed wage markup for workers of higher qualifications. This is indeed what we would expect given the higher unemployment rate for high-qualified workers. Only in six years (1986, 1988, 1994, 1995, 1996 and 1997 was there a certain shortage of the machine operators (L2) compared to manual workers (L1). There was never a shortage of qualified workers (L4 and higher) compared to non-qualified workers. In 2001, a worker's contribution to the economy in categories 1 to 5 was worth 1,659 dinars per year.

Unskilled workers are thus the crucial bottleneck for improved growth performance in Tunisia. The excessive wage rates for the more qualified workers were not justified according to our activity analysis. It is a fact that qualified labor is in excess supply in Tunisia. Highly qualified workers are more likely to be demanded by large firms and those are few in numbers in Tunisia. In 1996, according to a study of the World Bank (World Bank (2000a), vol. II, table 2.3, p.6) $82.4 \%$ of Tunisian enterprises had less than 6 workers, while only $1.6 \%$ employed more than 100 workers and a few dozens more than 500. This fact was confirmed in a recent report (World Bank, 2008), which found that about 90 percent of Tunisian firms are small and medium enterprises most of which are family-owned.

As equipment is sector-specific, sectors can expand only up to their full capacity. All sectors with full capacity earn a positive shadow price for their equipment. Sectors that are activated at less than full capacity earn no marginal return on their equipment. Table 2 reports the weighted average observed and optimal rates of return on buildings, equipment and the total capital stock. The optimal rate of return on buildings is the shadow price of constraint (8). The optimal rate of return on equipment is the weighted of the shadow prices of constraints (7). The optimal rate of return on the total capital stock is the weighted average of the shadow prices of buildings and equipment. To calculate the observed rates of return on buildings and equipment we followed the method used by the World Bank (World Bank, 1995). Assuming that interest payments are fully deductible, as they are in Tunisia, the user cost of physical capital is defined as: $\mathrm{c}=\mathrm{q}(\mathrm{r}(1-\mathrm{t})+\mathrm{d})$, where $q$ is the physical capital deflator (specific to each sector and each component of the capital stock), $r$ is the real lending rate ${ }^{4}, t$ is the corporate tax rate ${ }^{5}$, and $d$ is the depreciation rate (again specific to each sector and component of the capital stock) ${ }^{6}$. Fiscal and financial incentives have not been taken into account. The observed user cost for total capital is the weighted average of the observed user costs for buildings and equipment. As equipment depreciates faster than buildings the observed user cost of equipment is higher than the observed user cost of buildings. The same does not necessarily hold for the shadow prices of buildings and equipment.

The weighted average rate of return on physical capital dropped from 26.9 per cent in 1983 to 11 per cent in 1995 and rose afterwards to 30.8 per cent in 2001 (table 2). The social return on capital decreased after the structural adjustment program got

\footnotetext{
${ }^{4}$ The lending rate used is the money market rate plus 3 percentage points. Different preferential sectoral interest rates were not taken into consideration.

${ }^{5}$ To simplify the calculation, a 50\% flat tax rate is applied for 1983-88, and after the tax reform in 1989 the normal corporate tax of 35\% is applied for 1989-2001. Different tax rates for wholly exporting and agricultural enterprises and various tax holidays have not been considered.

${ }^{6}$ The average depreciation rate is of $2.9 \%$ for building and $6.7 \%$ for equipment.
} 
introduced showing that the Tunisian economy invested during this period and rates of return on capital got closer to the normal rate. From 1996 onwards, capital became more scarce again, even more than in 1983.

Table 3 compares for selected years the shadow and the observed commodity prices. We can distinguish two sub-periods. From 1983 to 1989 the shadow commodity prices that sustain the optimal allocation of resources in the competitive benchmark were higher than the observed commodity prices. Remember that in competitive equilibrium prices may not exceed average cost (equation 10). Therefore we can conclude that to survive in a competitive environment sectors would have had to price their output at higher than observed prices. Commodity prices were kept artificially low by regulation. Before the structural adjustment program, the price-fixing policy depressed competition in many sectors and discouraged innovation (Ghali (1995), Morrisson and Talbi (1996)). After 1989 the shadow commodity prices were below the observed prices, except for electricity and water, which implies that the non-utility sectors earned rents.

\section{The evolution of Tunisia's economic potential, 1983-2001}

We now turn to the definition and decomposition of frontier TFP growth. We define frontier TFP growth as the growth of final demand of business and non-business goods and services (where business goods and services refer to those for which there is an intermediate demand) minus the growth in the primary inputs (the endowments of the five types of labor, the capital stocks in each sector and the current trade deficit):

$$
\dot{T F P}=\frac{\left(p^{\prime} \dot{f}+w^{\prime} l\right)}{p^{\prime} f+w^{\prime} l}-\frac{\left(w^{\prime} \dot{N}+r^{\prime} \dot{M}+\varepsilon \dot{D}\right)}{w^{\prime} N+r^{\prime} M+\varepsilon D}
$$

where dots denote growth rates. This new definition of frontier TFP growth is a natural extension of the TFP concept at the sector level. Instead of computing the growth of production not due to the growth of the factors of production (the conventional definition of TFP growth), in an open economy and a macro-wide context TFP is defined as the growth in final domestic demand that cannot be explained by the growth in primary factor endowments. We call it frontier TFP growth because we measure it at the prices (or marginal productivities) and general activity level that solve the optimal program of resource allocation.

There are two ways to decompose frontier TFP growth. The first decomposition is in terms of the individual factor productivities. We start from the equality between the optimal values of the primal and the dual of the linear program, as stated by the first theorem of linear programming:

$$
D F D t=w^{\prime} N+r^{\prime} M+\varepsilon D .
$$

By doing so, we position ourselves at the frontier of the economy. If we totally differentiate (15) and make use of the normalization rule (11) we obtain, as derived by ten Raa and Mohnen (2002), that frontier TFP growth can be written as the weighted 
sum of the individual factor productivity growth rates, i.e. input prices, minus a weighted sum of the commodity prices, plus efficiency change:

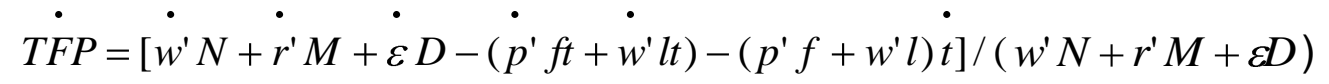

In other words, frontier TFP growth is equal to the sum of the individual factor productivity growth rates in real terms, corrected for a term that reflects the change in the position of the economy vis-à-vis the efficiency frontier. Notice that the last term is positive if $t$ declines, i.e. when the economy moves closer to the efficiency frontier. Deviations from the frontier correspond to deviations from perfect competition, which can also be regarded as departures from efficiency.

The second decomposition of frontier TFP growth is in terms of the evolution of the constraining factors in the optimization of welfare, in other words the exogenous variables of the model, which can be regarded as the drivers of frontier TFP growth (the labor and capital endowments, the trade deficit and the terms of trade). As shown by ten Raa and Mohnen (2002), expression (14) defining TFP growth can be rewritten as

where

$$
\stackrel{\cdot}{T F P}=S R+T T+E C+S L
$$

$$
\begin{aligned}
& S R=\left\{p^{\prime}(f t+\dot{J g})-w^{\prime}\left(\dot{L^{\prime}} s\right)-r^{\prime}\left(\dot{K^{\prime}} s\right)\right\} /\left[\left(p^{\prime} f t+w^{\prime} l t\right)\right] \\
& T T=\varepsilon \dot{\varepsilon} \pi^{\prime} g /\left(p^{\prime} f t+w^{\prime} l t\right) \\
& E C=-\left(p^{\prime} f+w^{\prime} l\right) \dot{t} /\left(p^{\prime} f t+w^{\prime} l t\right) \\
& S L=\left\{-w^{\prime}\left[\dot{N}-\left(L^{\prime} \dot{s}+l t\right)\right]-r^{\prime}\left[\dot{M}-\left(\dot{K^{\prime}} s\right)\right]-\varepsilon\left[\dot{\bar{D}}+\left(\dot{\pi^{\prime}} g\right)\right]\right\} /\left[\left(p^{\prime} f t+w^{\prime} l t\right)\right] .
\end{aligned}
$$

According to (17), frontier TFP growth can be decomposed into four terms: the Solow residual (SR), the terms of trade effect (TT), the efficiency change effect (EC), and the change in the slack in the use of primary inputs (SL).

The Solow residual is the traditional measure of TFP growth (value added growth minus the growth in the conventional inputs, labor and capital), except that here it is measured at optimal activity levels and shadow prices. The second term represents the terms of trade effect. An appreciation in the terms of trade gives the economy the opportunity to increase its final demand without augmenting the use of its primary inputs. The third term is the efficiency change: a decrease in the expansion factor of final demand implies a closer position to the efficiency frontier and translates into a higher TFP growth. The fourth term is the change in the slack factor: an increase [decrease] in slack, i.e. less than full resource utilization, decreases [increases] TFP growth. 
In table 4 and in subsequent tables we present the evolution of Tunisian frontier TFP growth and its components over the whole sample period (1983-2001) and different sub-periods, corresponding respectively to the $6^{\text {th }}(1982-1986), 7^{\text {th }}(1987-1991), 8^{\text {th }}$ (1992-1996) and $9^{\text {th }}$ (1997-2001) five-year Economic Development Plans.

As table 4 reveals, over the whole sample period (1983-2001) frontier TFP growth increased by a mere $0.2 \%$ per year. This poor global performance is especially due to the negative growth rates over the 1983-1986 period, when frontier TFP actually declined, in other words the economy's potential seriously deteriorated. After 1986, frontier TFP growth became positive again at about $1 \%$ per year. Regarding the decomposition of TFP growth into the input sources and beneficiaries of TFP growth, we notice that among the workers only manual workers and machine operators, i.e. the unskilled workers, play a major role. The shadow wage of machine operators increased in the first three periods and turned negative in the last period. For manual workers, the least qualified workers, it flipped from negative (or zero) to positive in each sub-period. The other categories of workers contributed only slightly to frontier TFP growth because of their relative small share in total employment.

On the whole, capital, especially equipment, had a negative contribution to TFP growth. Tunisia overinvested in equipment (see table 5). This was strikingly so during the 1983-1986 sub-period. The declines in equipment after 1991 were beneficial to aggregate TFP growth. The capital stock in buildings increased by $4.2 \%$ on average over the whole period. The increase was justified in terms of increasing potential TFP in 1983-1986, but no more afterwards. It must be recalled that in the period stretching from 1972 to 1985 real interest rates were negative in selected key sectors (Morrisson and Talbi (1995), World Bank (1996)). Investment policy changed in 1987. Investment which previously had to be approved was now given financial and fiscal incentives in some priority sectors. In 1993 a more unified code of investment was promulgated which was based on export promotion, regional development, and technological development.

The last primary input in our open model is the allowable trade deficit. Over the whole period it played a slightly negative but modest role in frontier TFP growth. The marginal value in terms of domestic final demand of one additional dinar of allowable trade deficit decreased by one tenth of a percentage point throughout the period. Commodity prices kept decreasing over time, thereby increasing the individual factor productivities in real terms. The optimal expansion of domestic final demand increased after 1992, which means that the economy moved further away from its efficiency frontier.

We now turn to the decomposition of frontier TFP growth in terms of the growth in the quantities of the exogenous variables. The Solow residual grew by $1 \%$ per year over the whole period. In 1983-1986 it actually regressed, but then it rose in the next three sub-periods to reach an annual growth rate of $2.2 \%$ in 1997-2001. The improvement in the Solow residual coincides with the structural adjustment program started in 1987. This policy aimed at increasing competition, liberalizing prices, the financial sector and foreign trade, reforming public enterprises, and privatizing certain sectors like the textile and the hotel industries. These reforms have been accelerated and amplified after the implementation of the industrial restructuring program in 1996. 
What is striking is the strong negative effect the terms of trade exerted on frontier TFP growth in the two sub-periods prior to 1992 and after 1997. The evolutions of world prices and of the exchange rate of the Tunisian dinar were not favorable to Tunisia. On average the price of imported goods rose more than the price of exported goods. In the end the Tunisian economy experienced over the whole period a significant drop in its purchasing power on world markets. Only in 1992-1996 was the evolution of the world prices compared to the domestic prices sustaining the equilibrium favorable to Tunisia. The terms of trade effect neutralized so to say the Solow residual effect.

While Tunisia managed to move its efficiency frontier outwards after 1986 (Solow residual), it also moved away from its efficiency frontier after 1992, as already noticed in the first frontier TFP decomposition. Changes in the slacks of resource utilization played only a minor role.

\section{Sector decomposition of Tunisia's Solow residual, 1983-2001}

The decompositions of TFP growth in (16) and (17), and in particular the Solow residual component, are decompositions at the macroeconomic level in a general equilibrium setting. However, we can also define sector Solow residuals that are consistent with the macroeconomic Solow residual by the Domar aggregation rule (see Hulten (1978)). Let $\mathrm{j}$ stand for sectors, $\mathrm{i}$ for commodities, and $\mathrm{k}$ for groups of sectors. The Solow residual for sector-group k can then be written as:

$$
S R_{k}=\frac{\sum_{j \in k} \sum_{i} p_{i} v_{j i} s_{j}\left(v_{j i} s_{j}\right)}{\sum_{j \in k} \sum_{i} p_{i} v_{j i} s_{j}}-\frac{\sum_{j \in k} \sum_{i} p_{i} u_{i j} s_{j}\left(u_{i j} s_{j}\right)}{\sum_{j \in k} \sum_{i} p_{i} v_{j i} s_{j}}-\frac{\sum_{j \in k} w^{\prime} L_{j} s_{j}\left(L_{j} s_{j}\right)}{\sum_{j \in k} \sum_{i} p_{i} v_{j i} s_{j}}-\frac{\sum_{j \in k} r_{j}^{\prime} K_{j} s_{j}\left(K_{j} s_{j}\right)}{\sum_{j \in k} \sum_{i} p_{i} v_{j i} s_{j}}
$$

Notice that when $\mathrm{k}=\mathrm{j}$, we get the Solow residual for sector $\mathrm{j}$.

According to the Domar aggregation rule:

$$
S R=\sum_{k} \frac{\sum_{j \in k} \sum_{i} p_{i} v_{j i} s_{j}}{\left(p^{\prime} f t+w^{\prime} l t\right)} S R_{k}
$$

We can thus define sector Solow residuals that by the Domar aggregation rule are consistent with our Solow residual component of frontier TFP growth. The Domar weights represent the ratio of optimal sector production and aggregate domestic final demand. Each sector gets a weight proportional to its direct and indirect (via interindustry transactions) contribution to domestic final demand. The Domar weights add thus up to more than 1.

Table 6 gives the weights used in the Domar aggregation of the sector Solow residuals to get to the aggregate Solow residual, which forms part of our second frontier TFP decomposition (equation (17)). Over the whole period the greatest weight is attached 
to services followed by textile, food processing, agriculture, and mechanical and electrical goods. The latter experienced a tremendous increase in its importance from an average of $2 \%$ in 1983-1986 to an average of $28 \%$ in 1997-2001. This change in industrial composition followed the government's decision to stop the assembly of private cars and negotiate with European car manufacturers the "rules of local content" for the import of the European cars. This decision led the initial growth of this sector and an increased vertical integration with the E.U car industry (World Bank, 2008). In contrast, the hydrocarbons sector's importance in its contribution to domestic final demand fell from $26 \%$ to $4 \%$ over the first and the last sub-periods.

In table 7 we compare the sector Solow residuals calculated at the activity levels and shadow prices that sustain the optimal general equilibrium with those calculated at observed activity levels and observed prices. It should first be noticed that the observed Solow residuals overestimate in general the Solow residuals consistent with the optimal program. The difference between the two measures is perhaps most evident in the case of mining. In the optimal allocation of resources mining should not be activated. It would be more economical to specialize in sectors where Tunisia has a comparative advantage and use the import proceeds to import the mining goods. Consequently there is no Solow residual for mining at the optimal activity level. In practice, though, there is activity in mining and hence also a Solow residual, which is actually sizeable. Over the period 1983-2001 the Solow residual evaluated at the optimal allocation of resources was highest in electricity, water, and hydrocarbons. Those are the strong sectors of the Tunisian economy. But it is also worth noticing that the mechanical, electrical and textile goods sectors that faced increased international competition maintained a high Solow residual, implying that they were able to adjust to increased competitiveness. Substantial improvements in the Solow residual took place in the services sectors that turned from negative before 1991 to positive afterwards in contrast to agriculture whose Solow residual continuously declined. The Tunisian economy is thus well under way in moving from a primary to a tertiary economy.

\section{Conclusion}

In this study we have examined the evolution of frontier TFP in Tunisia over the period 1983-2001 using the framework of ten Raa and Mohnen (2002). Frontier TFP growth captures the shift in the production frontier of the economy as well as variations in efficiency movements with respect to the frontier. The location of the frontier is obtained by the resolution of a linear program (or activity analysis) at the level of the whole economy, taking into account factor resource constraints, interindustry linkages, preferences and world prices. We have proceeded to two decompositions of TFP growth. One decomposes it with respect to the individual marginal productivities: capital subdivided into buildings and equipment, labor subdivided into five levels of qualification, and the allowable trade deficit. The second one is with respect to the exogenous variables of the model, yielding four terms: the usual Solow residual (but evaluated at frontier quantities and supporting prices), the terms of trade effect, the economy's efficiency and the extent of incomplete resource utilization.

The main results of our analysis can be summarized in the following points: 
Between 1983 and 2001 frontier TFP growth hardly increased in Tunisia. This poor global performance is especially due to the negative growth rates over the 1983-1986 period, where the economy's potential actually deteriorated. After the introduction of the structural adjustment program, frontier TFP growth increased by about $1 \%$ per year.

With the exception of the last sub-period corresponding to the 9th Five-Year Development Plan, it was labor productivity and not capital productivity that was the main contributor to frontier TFP growth, and in particular unskilled labor. The allowable trade deficit played a slightly negative but modest role in frontier TFP growth over the whole period. Commodity prices kept decreasing all the time, thereby increasing frontier TFP growth.

The Solow residual computed at frontier levels grew by $1 \%$ per year over the whole period and kept increasing after the structural adjustment program, which started in 1987. It even accelerated after the implementation of the industrial restructuring program in 1996. What is striking is the strong negative effect the terms of trade exerted on frontier TFP growth in all sub-periods, except between 1992 and 1996. The evolution of world prices and the value of the Tunisian dinar were not favorable to Tunisian frontier TFP growth. Tunisia managed more efficiently its primary resources until 1992, and then it moved away from its efficiency frontier while the frontier kept moving outwards.

These results indicating changing trends and deep restructurings in the Tunisian economy should nevertheless be taken with some reservations. Nugent (1970) already pointed out that activity analysis models like this one may depend heavily on model and data imperfections. Data on capacity utilizations and labor force by type of qualification are partly constructed and hence particularly subject to measurement errors. Quantities are hard to measure in the service sectors and future studies will certainly improve our measure of productivity in services. The same could be said about quality changes with possible mismeasurement of output, especially in hightech commodities. It would be more rewarding to have a disaggregation of labor by skills rather than by occupations. Finally, adjustment lags and expectations are completely absent from this static model. Introducing dynamics into the model would call for an intertemporal optimization model. It may well be that what is regarded as bad performance in the short run could turn out to be beneficial in a long-run perspective. 


\section{Bibliography}

Balk, B. (1998), Industrial Price, Quantity, and Productivity Indices: The MicroEconomic Theory and an Application. Kluwer Academic Publishers, Boston.

Barro, R. J. (1999), "Notes on Growth accounting", Journal of Economic Growth, 4, 119-137.

Bsaies, A., M. Goaied et R. Baccouche (1995), "Etude de la productivité globale des facteurs: Analyse globale", Notes et Documents de Travail, No 04-95, Institut d'Economie Quantitative, Septembre.

Bosworth, B., S. Collins and Y. C. Chen (1995), "Accounting for Differences in Economic Growth", Brookings Discussion Papers in International Economics, No 115.

Caves, D.W., L.R. Christensen and W.E. Diewert (1982), "The Economic Theory of Index Numbers and the Measurement of Input, Output, and Productivity", Econometrica, 50, 1393-1414.

Diewert, W. E. (1976), "Exact and Superlative Index Numbers", Journal of Econometrics, 4, 115-145.

Diewert, W. E. (1981), "The Theory of Total Factor Productivity Measurement in Regulated Industries", in Cowing, T. and R. Stevenson (eds.), Productivity Measurement in Regulated Industries, Academic Press, New York.

Diewert, W. E. (1992), "The Measurement of Productivity", Bulletin of Economic Research, 44(3), 163-198.

Diewert, W. E. and C.J. Morrison (1986), "Adjusting Output and Productivity Indexes for Change in the Terms of Trade", Economic Journal, 96, 659-679.

Domar, E. (1961), "On the Measurement of Technical Change", Economic Journal, 70, 710-729.

Färe, R., Grosskopf S., Norris M. and Zhang Z. (1994), "Productivity Growth, Technical Progress, and Efficiency Change in Industrialized Countries", American Economic Review, 84, 1, March, 66-83.

Farrell, M. J. (1957), "The Measurement of Productivity Efficiency", Journal of Royal Statistical Society A, 120, 253-281.

Fuentes, H.J., E. Grifell-Tatjé, and S. Perelman (2001), "A Parametric Distance Function Approach for Malmquist Productivity Index Estimation", Journal of Productivity Analysis, 15, 79-94.

Ghali, S. (1995), "Régimes des prix et organisation de la concurrence", in Schéma Global de Développement de l'Economie Tunisienne à l'Horizon 2010, Etude stratégique No 3, Vol III, Institut d'Economie Quantitative, Novembre. 
Ghali, S. and P. Mohnen (2003), "Restructuring and Economic Performance: The Experience of the Tunisian Economy", in Trade Policy and Economic Integration in the Middle East and North Africa: Economic Boundaries in Flux, (Hassan Hakimian and Jeffrey B Nugent, eds.), London: Routledge-Curzon.

Grosskopf, S. (2001), "Some Remarks on Productivity and its Decompositions", mimeo.

Hall, R.E. (1990), "Invariance Properties of Solow's Residual", in Diamond, P. (ed.), Growth / Productivity / Unemployment, M.I.T Press, Cambridge, M.A.

Hulten, C. R. (1978), "Growth Accounting with Intermediate Inputs", Review of Economic Studies, 45, 511-518.

Institut d'Économie Quantitative (1996), Étude stratégique No. 8, compétitivité, restructuration, diversification et ouverture sur l'extérieur des industries manufacturières et des services, 8622/96.

Institut National de la Statistique, Les comptes de la nation.

International Monetary Fund (1999), Tunisia: Staff Report for the Article IV Consultation, IMF Staff Country Report No. 99/104, September, Washington D.C.

Jorgenson, D. W. and Z. Griliches (1967), "The Explanation of Productivity Change", Review of Economic Studies, 34(3), 308-350.

Kohli, U. (1991), Technology, Duality, and Foreign Trade: The GNP Function Approach to Modelling Imports and Exports, Ann Arbor: University of Michigan Press.

Ministère du Développement Economique et de la Coopération Internationale (1992), VIII ème Plan de Développement, 1992-1996, Contenu Global, Vol I, République Tunisienne.

Ministère du Développement Economique et de la Coopération Internationale (1996), IX ème Plan de Développement, 1996-2001, Contenu Global, Vol I, République Tunisienne.

Morrisson, C. and B. Talbi (1996), La croissance de l'économie tunisienne en longue période. Centre de développement de l'OCDE.

Nugent, J. (1970), "Linear Programming Models for National Planning: Demonstration of a Testing Procedure", Econometrica, 38(6), 831-855.

Redjeb, M.S. et B. Talbi (1995), "Performance de l'Economie Tunisienne durant la Période 1961-1993", in Schéma Global de Développement de l'Economie Tunisienne à $l^{\prime}$ Horizon 2010, Etude stratégique No 3, Vol II, Institut d'Economie Quantitative, Novembre. 
Redjeb, M. S. et L. Bouzaiane (1999), "Contribution du secteur privé à la croissance économique en Tunisie", in L'entreprise au seuil du troisième millénaire: Défis et Enjeux, Institut Arabe des Chefs d'Entreprises, Novembre.

Solow, R. (1957), "Technical Change and the Aggregate Production Function", Review of Economics and Statistics, 39, 312-320.

ten Raa, T. and P. Mohnen (2002), " Neoclassical Growth Accounting and Frontier Analysis: A Synthesis ", Journal of Productivity Analysis, 18, 111-128.

World Bank (1995), Republic of Tunisia, Poverty Alleviation: Preserving Progress while Preparing for the Future, Report No. 13993-TUN, Vol II, August. Washington D.C.

World Bank (1996), Tunisia's Global Integration and Sustainable Development, Strategic Choices for the 21. Washington D.C.

World Bank (2000a), Tunisia-Private Sector Assessment Update, Meeting the Challenge of Globalization, report No.20173-TUN, December. Washington D.C.

World Bank (2000b), Republic of Tunisia. Social and Structural Review 2000. Washington D.C.

World Bank (2008), Tunisia's Global Integration: Second Generation of Reform to Boost Growth and Employment, report No.40129-TUN, May. Washington D.C. 
Table 1

Observed and shadow prices of labor for different levels of qualification (1983-2001). (1,000 DT per year, 1990 prices)

\begin{tabular}{|c|c|c|c|c|c|c|c|c|c|c|}
\hline & \multicolumn{2}{|c|}{ L 1} & \multicolumn{2}{|c|}{ L 2} & \multicolumn{2}{|c|}{ L 3} & \multicolumn{2}{|c|}{ L 4} & \multicolumn{2}{|c|}{ L 5} \\
\hline & observed & shadow & observed & shadow & observed & shadow & observed & shadow & observed & shadow \\
\hline 1983 & 1.143 & 0.246 & 1.934 & 0.246 & 2.968 & 0.246 & 4.158 & 0.246 & 5.605 & 0.246 \\
\hline 1984 & 1.109 & 0.846 & 1.913 & 0.846 & 3.025 & 0.846 & 4.039 & 0.846 & 5.450 & 0.846 \\
\hline 1985 & 1.015 & 1.832 & 1.983 & 1.832 & 2.639 & 1.832 & 3.648 & 1.832 & 5.059 & 1.832 \\
\hline 1986 & 1.007 & 0.340 & 1.689 & 0.749 & 2.621 & 0.749 & 3.858 & 0.749 & 5.047 & 0.749 \\
\hline 1987 & 0.874 & 0.781 & 1.740 & 0.781 & 2.422 & 0.781 & 3.211 & 0.781 & 4.365 & 0.781 \\
\hline 1988 & 0.954 & 0.000 & 1.591 & 0.472 & 2.477 & 0.472 & 3.713 & 0.472 & 4.810 & 0.472 \\
\hline 1989 & 0.906 & 0.016 & 1.742 & 0.016 & 2.447 & 0.016 & 3.243 & 0.016 & 4.556 & 0.016 \\
\hline 1990 & 1.000 & 1.451 & 1.617 & 1.451 & 2.466 & 1.451 & 3.760 & 1.451 & 5.036 & 1.451 \\
\hline 1991 & 0.929 & 1.581 & 1.788 & 1.581 & 2.385 & 1.581 & 3.358 & 1.581 & 4.671 & 1.581 \\
\hline 1992 & 1.097 & 1.242 & 1.752 & 1.242 & 2.786 & 1.242 & 3.844 & 1.242 & 5.516 & 1.242 \\
\hline 1993 & 1.016 & 1.282 & 1.919 & 1.282 & 2.646 & 1.282 & 3.474 & 1.282 & 5.172 & 1.282 \\
\hline 1994 & 1.125 & 1.743 & 1.788 & 1.992 & 2.765 & 1.992 & 3.829 & 1.992 & 5.657 & 1.992 \\
\hline 1995 & 1.065 & 0.599 & 1.838 & 3.221 & 2.236 & 3.221 & 3.591 & 3.221 & 5.403 & 3.221 \\
\hline 1996 & 1.200 & 0.177 & 1.756 & 2.050 & 3.007 & 2.050 & 4.138 & 2.050 & 6.080 & 2.050 \\
\hline 1997 & 1.214 & 0.000 & 1.879 & 2.040 & 3.010 & 2.040 & 4.219 & 2.040 & 6.102 & 2.040 \\
\hline 1998 & 1.219 & 0.000 & 1.880 & 0.000 & 3.004 & 0.000 & 4.266 & 0.000 & 6.164 & 0.000 \\
\hline 1999 & 1.272 & 0.000 & 1.915 & 0.000 & 3.183 & 0.000 & 4.373 & 0.000 & 6.403 & 0.000 \\
\hline 2000 & 1.315 & 0.000 & 1.943 & 0.000 & 3.349 & 0.000 & 4.506 & 0.000 & 6.603 & 0.000 \\
\hline 2001 & 1.364 & 1.659 & 2.006 & 1.659 & 3.442 & 1.659 & 4.647 & 1.659 & 6.866 & 1.659 \\
\hline
\end{tabular}

L1: manual workers/trainees, L2: machine operators, L3: foremen, L4: technicians, L5: engineers/administrators DT: Tunisian Dinar 
Table 2

Observed and shadow weighted average of sector level rates of return of capital stock $(\mathrm{K})$ decomposed into buildings (KB) and equipment (KE) (1983-2001).

(Weighted average of sector level rates of return, expressed in base-year (1990) prices).

\begin{tabular}{|l|c|c|c|c|c|c|}
\hline & \multicolumn{2}{|c|}{ Total capital } & \multicolumn{2}{c|}{ Equipment } & \multicolumn{2}{c|}{ Buildings } \\
\cline { 2 - 7 } observed & optimal & observed & optimal & observed & optimal \\
\hline $\mathbf{1 9 8 3}$ & 0.026 & 0.269 & 0.027 & 0.308 & 0.024 & 0.219 \\
\hline $\mathbf{1 9 8 4}$ & 0.032 & 0.209 & 0.033 & 0.229 & 0.031 & 0.183 \\
\hline $\mathbf{1 9 8 5}$ & 0.045 & 0.166 & 0.047 & 0.178 & 0.043 & 0.151 \\
\hline $\mathbf{1 9 8 6}$ & 0.054 & 0.193 & 0.057 & 0.145 & 0.049 & 0.253 \\
\hline $\mathbf{1 9 8 7}$ & 0.057 & 0.189 & 0.068 & 0.142 & 0.044 & 0.245 \\
\hline $\mathbf{1 9 8 8}$ & 0.062 & 0.209 & 0.076 & 0.199 & 0.047 & 0.221 \\
\hline $\mathbf{1 9 8 9}$ & 0.076 & 0.214 & 0.093 & 0.156 & 0.058 & 0.279 \\
\hline $\mathbf{1 9 9 0}$ & 0.102 & 0.148 & 0.122 & 0.111 & 0.081 & 0.188 \\
\hline $\mathbf{1 9 9 1}$ & 0.100 & 0.143 & 0.123 & 0.096 & 0.076 & 0.192 \\
\hline $\mathbf{1 9 9 2}$ & 0.127 & 0.181 & 0.152 & 0.128 & 0.100 & 0.235 \\
\hline $\mathbf{1 9 9 3}$ & 0.140 & 0.188 & 0.171 & 0.165 & 0.110 & 0.211 \\
\hline $\mathbf{1 9 9 4}$ & 0.125 & 0.160 & 0.158 & 0.169 & 0.093 & 0.152 \\
\hline $\mathbf{1 9 9 5}$ & 0.114 & 0.110 & 0.152 & 0.093 & 0.082 & 0.125 \\
\hline $\mathbf{1 9 9 6}$ & 0.147 & 0.194 & 0.201 & 0.204 & 0.102 & 0.186 \\
\hline $\mathbf{1 9 9 7}$ & 0.137 & 0.188 & 0.198 & 0.188 & 0.090 & 0.187 \\
\hline $\mathbf{1 9 9 8}$ & 0.147 & 0.294 & 0.214 & 0.356 & 0.098 & 0.249 \\
\hline $\mathbf{1 9 9 9}$ & 0.145 & 0.299 & 0.213 & 0.389 & 0.098 & 0.238 \\
\hline $\mathbf{2 0 0 0}$ & 0.142 & 0.301 & 0.208 & 0.482 & 0.098 & 0.183 \\
\hline $\mathbf{2 0 0 1}$ & 0.156 & 0.308 & 0.223 & 0.216 & 0.114 & 0.199 \\
\hline
\end{tabular}


Table 3

Observed (obs.) and shadow (shad.) commodity prices (selected years).

(base year: 1990)

\begin{tabular}{|c|c|c|c|c|c|c|c|c|c|c|c|c|c|c|}
\hline & \multicolumn{2}{|c|}{1984} & \multicolumn{2}{|c|}{1987} & \multicolumn{2}{|c|}{1990} & \multicolumn{2}{|c|}{1993} & \multicolumn{2}{|c|}{1996} & \multicolumn{2}{|c|}{1999} & \multicolumn{2}{|c|}{2001} \\
\hline & obs. & shad. & obs. & shad. & obs. & shad. & obs. & shad. & obs. & shad. & obs. & shad. & obs. & shad. \\
\hline Agric \& Fishing & 0.658 & 0.855 & 0.794 & 0.837 & 1.000 & 0.951 & 1.120 & 0.901 & 1.227 & 0.786 & 1.315 & 0.774 & 1.426 & 1.030 \\
\hline Food process & 0.650 & 0.771 & 0.838 & 0.885 & 1.000 & 0.951 & 1.167 & 0.721 & 1.397 & 1.104 & 1.515 & 0.880 & 1.596 & 0.702 \\
\hline Const material & 0.762 & 1.175 & 0.840 & 1.081 & 1.000 & 0.951 & 1.147 & 0.988 & 1.241 & 0.909 & 1.311 & 1.086 & 1.385 & 1.331 \\
\hline Mechan \& Elect & 0.616 & 0.969 & 0.775 & 1.050 & 1.000 & 0.951 & 1.116 & 1.067 & 1.263 & 0.867 & 1.409 & 1.431 & 1.490 & 1.255 \\
\hline Chem \& Rubb & 0.747 & 1.515 & 0.814 & 1.092 & 1.000 & 0.951 & 1.083 & 0.864 & 1.329 & 0.926 & 1.385 & 0.989 & 1.368 & 0.779 \\
\hline Text \& Leather & 0.592 & 0.970 & 0.767 & 1.019 & 1.000 & 0.951 & 1.217 & 1.085 & 1.434 & 1.028 & 1.553 & 1.085 & 1.619 & 0.912 \\
\hline Other Manuf & 0.654 & 0.919 & 0.790 & 0.983 & 1.000 & 0.951 & 1.136 & 1.068 & 1.209 & 0.907 & 1.306 & 1.106 & 1.371 & 0.855 \\
\hline Mining & 0.902 & 1.405 & 0.743 & 0.913 & 1.000 & 0.951 & 0.906 & 0.964 & 1.188 & 0.709 & 1.526 & 0.881 & 1.514 & 0.738 \\
\hline Hydrocarbons & 0.868 & 1.955 & 0.867 & 1.016 & 1.000 & 0.951 & 0.992 & 0.775 & 1.042 & 0.745 & 1.156 & 0.722 & 1.447 & 1.064 \\
\hline Electricity & 0.886 & 2.377 & 0.951 & 1.960 & 1.000 & 1.506 & 1.108 & 1.447 & 1.219 & 1.268 & 1.345 & 1.461 & 1.443 & 1.480 \\
\hline Water & 0.714 & 2.700 & 0.858 & 3.198 & 1.000 & 2.700 & 1.177 & 2.681 & 1.366 & 2.408 & 1.437 & 2.524 & 1.508 & 2.274 \\
\hline Construction & 0.707 & 0.841 & 0.828 & 0.846 & 1.000 & 0.879 & 1.210 & 0.877 & 1.281 & 0.862 & 1.424 & 0.783 & 1.494 & 0.940 \\
\hline Transp \&Comm & 0.681 & 1.188 & 0.855 & 1.127 & 1.000 & 0.951 & 1.222 & 1.086 & 1.294 & 0.941 & 1.327 & 1.011 & 1.416 & 0.909 \\
\hline Hot \& Tourism & 0.648 & 1.234 & 0.804 & 1.103 & 1.000 & 0.951 & 1.268 & 1.165 & 1.533 & 1.033 & 1.719 & 1.056 & 1.788 & 0.886 \\
\hline Other Services & 0.578 & 1.222 & 0.826 & 1.089 & 1.000 & 0.951 & 1.183 & 1.056 & 1.349 & 0.982 & 1.468 & 1.067 & 1.575 & 0.918 \\
\hline
\end{tabular}


Table 4

Decomposition of Frontier Total Factor Productivity Growth (1983-2001 and various sub-periods)

\begin{tabular}{|c|c|c|c|c|c|}
\hline & 1983-2001 & 1983-1986 & 1987-1991 & 1992-1996 & 1997-2001 \\
\hline $\begin{array}{c}\text { TOTAL } \\
\end{array}$ & 0.2 & -4.6 & 1.0 & 1.1 & 1.0 \\
\hline Manual workers and trainees & 0.3 & 0.0 & 1.3 & -1.4 & 1.7 \\
\hline Machine operators & 0.8 & 1.2 & 2.8 & 2.5 & -1.6 \\
\hline Foremen & 0.1 & 0.2 & 0.4 & 0.4 & -0.2 \\
\hline Technicians & 0.1 & 0.3 & 0.4 & 0.3 & -0.2 \\
\hline Engineers/administrators & 0.1 & 0.1 & 0.2 & 0.2 & -0.1 \\
\hline Equipment & -1.4 & -10.0 & -3.0 & 2.6 & 1.0 \\
\hline Trade deficit & -0.1 & -0.1 & -0.1 & -0.1 & -0.1 \\
\hline Changes in commodity prices & 0.2 & 0.6 & 0.2 & 0.1 & 0.1 \\
\hline Efficiency & 0.2 & 0.8 & 1.2 & -1.4 & -0.1 \\
\hline Solow Residual & 1.0 & -2.5 & 0.8 & 1.5 & 2.2 \\
\hline Terms of trade & -1.0 & -2.7 & -0.8 & 0.7 & -1.0 \\
\hline Efficiency & 0.2 & 0.8 & 1.2 & -1.4 & -0.1 \\
\hline Resource utilization & 0.0 & -0.2 & -0.2 & 0.3 & -0.1 \\
\hline
\end{tabular}


Table 5

Annual growth rates of labor (by type), capital (by type) and trade deficit

(in percentages)

\begin{tabular}{|c|c|c|c|c|c|}
\hline & 1983-2001 & 1983-1986 & 1987-1991 & 1992-1996 & 1997-2001 \\
\hline Manual workers and trainees & 1.1 & 0.2 & 1.7 & 0.6 & 1.2 \\
\hline Machine operators & 2.9 & 3.5 & 3.0 & 2.8 & 2.8 \\
\hline Foremen & 3.0 & 3.2 & 3.8 & 3.1 & 3.2 \\
\hline Technicians & 2.9 & 1.5 & 2.8 & 3.3 & 2.6 \\
\hline Engineers/administrators & 3.5 & 7.0 & 2.6 & 3.1 & 2.9 \\
\hline Total labor & 2.5 & 2.6 & 2.7 & 2.3 & 2.5 \\
\hline Equipment & 0.6 & 4.9 & 0.3 & -1.1 & -0.5 \\
\hline Buildings & 4.2 & 5.9 & 3.4 & 4.7 & 4.5 \\
\hline Total capital & 2.6 & 5.3 & 1.7 & 2.0 & 2.5 \\
\hline Trade deficit & -0.2 & -12.8 & 13.1 & -64.6 & 34.1 \\
\hline
\end{tabular}


Table 6

Solow residual (SR) at optimal activity levels and shadow prices (1983-2001), (annual growth rates in percentages) and mean weights in Domar aggregation

\begin{tabular}{|c|c|c|c|c|c|c|c|c|c|c|}
\hline & \multicolumn{2}{|c|}{ 1983-2001 } & \multicolumn{2}{|c|}{ 1983-1986 } & \multicolumn{2}{|c|}{ 1987-1991 } & \multicolumn{2}{|c|}{$1992-1996$} & \multicolumn{2}{|c|}{ 1997-2001 } \\
\hline & SR & weights & SR & weights & SR & weights & SR & weights & SR & weights \\
\hline Agriculture and fishing & -0.1 & 0.21 & -0.2 & 0.24 & -0.3 & 0.26 & -2.2 & 0.21 & -2.1 & 0.12 \\
\hline Food processing & 0.7 & 0.24 & -0.4 & 0.11 & -0.6 & 0.34 & -0.6 & 0.14 & 4.2 & 0.26 \\
\hline Construction materials \& glass & 1.5 & 0.02 & 10.0 & 0.00 & 0.0 & 0.00 & 0.7 & 0.00 & -1.5 & 0.11 \\
\hline Mechanical and electrical goods & 1.0 & 0.20 & 0.6 & 0.02 & 0.7 & 0.20 & 0.7 & 0.19 & 2.7 & 0.28 \\
\hline Chemical and rubber products & 0.8 & 0.00 & 0.0 & 0.00 & 0.0 & 0.00 & 7.8 & 0.00 & 1.2 & 0.00 \\
\hline Textile and leather products & 1.1 & 0.24 & 1.2 & 0.10 & 1.2 & 0.24 & 1.3 & 0.27 & 1.1 & 0.29 \\
\hline Other manufacturing & 0.6 & 0.09 & 0.8 & 0.01 & 0.2 & 0.10 & 0.9 & 0.10 & 0.2 & 0.11 \\
\hline Mining & 0.0 & 0.00 & 0.0 & 0.00 & 0.0 & 0.00 & 0.0 & 0.00 & 0.0 & 0.00 \\
\hline Hydrocarbons & 1.7 & 0.11 & 1.1 & 0.26 & 1.5 & 0.13 & -3.4 & 0.04 & 8.5 & 0.04 \\
\hline Electricity & 1.5 & 0.04 & 0.5 & 0.03 & 2.8 & 0.04 & 1.6 & 0.03 & 0.7 & 0.05 \\
\hline Water & 1.2 & 0.02 & 0.2 & 0.02 & -0.5 & 0.03 & 1.9 & 0.02 & 1.6 & 0.02 \\
\hline Construction and public works & 0.7 & 0.15 & 1.5 & 0.16 & 0.5 & 0.12 & 1.6 & 0.17 & 0.9 & 0.16 \\
\hline Transport and telecom. & 0.9 & 0.11 & -0.8 & 0.06 & -0.1 & 0.08 & 1.2 & 0.15 & 1.3 & 0.17 \\
\hline Hotel and tourism & 0.4 & 0.13 & -1.2 & 0.12 & -2.8 & 0.13 & 1.5 & 0.14 & 0.7 & 0.13 \\
\hline Other services & -0.1 & 0.43 & -5.2 & 0.44 & -0.4 & 0.42 & 2.3 & 0.42 & 1.0 & 0.45 \\
\hline $\begin{array}{l}\text { Aggregate } \\
\end{array}$ & 1.0 & 1.97 & -2.5 & 1.58 & 0.8 & 2.09 & 1.5 & 1.87 & 2.2 & 2.19 \\
\hline
\end{tabular}


Table 7

Sector Solow residuals at observed and optimal prices and activity levels (1983-2001) (annual growth rates in percentages)

\begin{tabular}{|c|c|c|c|c|c|c|c|c|c|c|}
\hline & \multicolumn{2}{|c|}{ 1983-2001 } & \multicolumn{2}{|c|}{ 1983-1986 } & \multicolumn{2}{|c|}{ 1987-1991 } & \multicolumn{2}{|c|}{ 1992-1996 } & \multicolumn{2}{|c|}{ 1997-2001 } \\
\hline & observed & optimal & observed & Optimal & Observed & optimal & observed & optimal & observed & optimal \\
\hline Agriculture and fishing & 1.6 & -0.1 & 1.7 & -0.2 & 1.4 & -0.3 & -0.9 & -2.2 & 0.0 & -2.1 \\
\hline Food processing & 0.8 & 0.7 & 1.9 & -0.4 & -0.4 & -0.6 & 0.3 & -0.6 & 0.8 & 4.2 \\
\hline Construction materials \& glass & 1.1 & 1.5 & -0.4 & 10.0 & 0.0 & 0.0 & 3.3 & 0.7 & 1.6 & -1.5 \\
\hline Mechanical and electrical goods & 1.1 & 1.0 & 1.4 & 0.6 & 0.9 & 0.7 & 0.7 & 0.7 & 2.1 & 2.7 \\
\hline Chemical and rubber products & 0.5 & 0.8 & 1.0 & 0.0 & 1.6 & 0.0 & 0.3 & 7.8 & 0.0 & 1.2 \\
\hline Textile and leather products & 1.4 & 1.1 & 1.1 & 1.2 & 1.9 & 1.2 & 1.5 & 1.3 & 1.3 & 1.1 \\
\hline Other manufacturing & 0.8 & 0.6 & 2.0 & 0.8 & 0.2 & 0.2 & 0.8 & 0.9 & 0.3 & 0.2 \\
\hline Mining & 1.8 & 0.0 & 0.5 & 0.0 & 0.8 & 0.0 & 0.4 & 0.0 & 3.9 & 0.0 \\
\hline Hydrocarbons & 0.7 & 1.7 & 2.6 & 1.1 & 1.6 & 1.5 & 0.0 & -3.4 & -1.2 & 8.5 \\
\hline Electricity & 0.2 & 1.5 & 2.5 & 0.5 & 0.0 & 2.8 & 0.9 & 1.6 & -2.3 & 0.7 \\
\hline Water & 1.4 & 1.2 & 0.4 & 0.2 & -3.3 & -0.5 & 5.3 & 1.9 & 2.1 & 1.6 \\
\hline Construction and public works & 0.9 & 0.7 & -0.3 & 1.5 & 0.7 & 0.5 & 1.9 & 1.6 & 2.5 & 0.9 \\
\hline Transport and telecom. & 2.0 & 0.9 & 0.2 & -0.8 & 0.1 & -0.1 & 4.1 & 1.2 & 2.0 & 1.3 \\
\hline Hotel and tourism & 1.4 & 0.4 & 1.0 & -1.2 & -2.0 & -2.8 & 1.7 & 1.5 & 1.7 & 0.7 \\
\hline Other services & 1.1 & -0.1 & -2.7 & -5.2 & 1.4 & -0.4 & 1.6 & 2.3 & 2.5 & 1.0 \\
\hline Aggregate & 2.2 & 1.0 & 0.8 & -2.5 & 1.4 & 0.8 & 2.2 & 1.5 & 2.6 & 2.2 \\
\hline
\end{tabular}


Appendix I: Industry nomenclature and symbols

\begin{tabular}{|l|c|}
\hline \multicolumn{1}{|c|}{ Industry } & Commodity code \\
\hline \multicolumn{2}{|c|}{ MGRICULTURE \& FISHING } \\
\hline Agriculture \& fishing \\
\hline \multicolumn{2}{|c|}{ MANUFACTURING } \\
\hline Food processing & 10 \\
\hline Construction materials \& glass & 20 \\
\hline Mechanical \& Electrical goods & 30 \\
\hline Chemical \& Rubber products & 40 \\
\hline Textile \& Leather products & 50 \\
\hline Other Manufacturing & 60 \\
\hline \multicolumn{2}{|c|}{ STILITIES } \\
\hline Mining & 65 \\
\hline Hydrocarbons & 66 \\
\hline Electricity & 67 \\
\hline Water & 68 \\
\hline Construction \& Public works & 69 \\
\hline \multicolumn{2}{|c|}{ SERVICES } \\
\hline Transport \&Communications & 76 \\
\hline Hotels \& Tourism & $79+99$ \\
\hline - Hotels, coffees and restaurants & 79 \\
\hline - Tourism and other stays & 99 \\
\hline Other Services & $72+82+85+94$ \\
\hline - Commodity trade & 82 \\
\hline - Financial services and insurance & 94 \\
\hline - Other market services & 72 \\
\hline - Non market services & \\
\hline
\end{tabular}

